\title{
Generation of methanol and ethanol from inhibited mineral oil
}

DOI:

10.23919/INSUCON.2017.8097205

\section{Document Version}

Accepted author manuscript

Link to publication record in Manchester Research Explorer

\section{Citation for published version (APA):}

Matharage, S., Liu, Q., Wang, Z., Wilson, G., Dyer, P., \& Mavrommatis, P. (2017). Generation of methanol and ethanol from inhibited mineral oil. In 13th International Electrical Insulation Conference (INSUCON), 2017 INSUCON (pp. 1) https://doi.org/10.23919/INSUCON.2017.8097205

\section{Published in:}

13th International Electrical Insulation Conference (INSUCON), 2017 INSUCON

\section{Citing this paper}

Please note that where the full-text provided on Manchester Research Explorer is the Author Accepted Manuscript or Proof version this may differ from the final Published version. If citing, it is advised that you check and use the publisher's definitive version.

\section{General rights}

Copyright and moral rights for the publications made accessible in the Research Explorer are retained by the authors and/or other copyright owners and it is a condition of accessing publications that users recognise and abide by the legal requirements associated with these rights.

\section{Takedown policy}

If you believe that this document breaches copyright please refer to the University of Manchester's Takedown Procedures [http://man.ac.uk/04Y6Bo] or contact uml.scholarlycommunications@manchester.ac.uk providing relevant details, so we can investigate your claim.

\section{OPEN ACCESS}




\title{
GENERATION OF METHANOL AND ETHANOL FROM INHIBITED MINERAL OIL
}

\author{
S.Y. Matharage ${ }^{1}$, Q. Liu ${ }^{1}$, Z.D. Wang ${ }^{1}$, G. Wilson ${ }^{2}$, P. Dyer ${ }^{3}$ and P. Mavrommatis ${ }^{4}$ \\ ${ }^{1}$ The University of Manchester, Manchester, M13 9PL, UK \\ ${ }^{2}$ National Grid, Warwick, CV34 6DA, UK \\ ${ }^{3}$ UK Power Networks, Crawley, RH10 0FL, UK \\ ${ }^{4}$ TJ/H2b Analytical Services Ltd, Bromborough, CH62 4SU, UK
}

\section{INTRODUCTION}

Ageing assessment of transformer paper insulation is commonly conducted through measurement of different chemical indicators in oil such as carbon oxide gases and furanic compounds [1]. Apart from these conventional paper ageing indicators, recent research success has shown that methanol and ethanol in transformers can also be used to indicate the degradation of transformer paper insulation [2].

Methanol and ethanol in transformer oil are commonly measured through methods developed using headspace gas chromatography units combined with either mass spectrometry or flame ionisation detection units [3, 4]. Laboratory ageing experiments have shown a linear variation of methanol against the paper ageing. Therefore, it was suggested to use methanol to indicate normal paper ageing, which occurs mainly through the hydrolysis process [2]. On the other hand, a high amount of ethanol was observed from the ageing of laevoglucosan, a pyrolysis by-product of paper ageing. Therefore, it was suggested to use ethanol to indicate abnormal paper ageing that occurs at very high temperatures $[2,5]$.

Apart from paper, oils themselves produced methanol and ethanol during their ageing process [6]. During a laboratory ageing experiment conducted at $120{ }^{\circ} \mathrm{C}$ under sealed conditions, the amount of methanol measured during an oil-only ageing experiment conducted with hydrocarbon oils was less than $10 \%$ of the amount measured during the oil-paper ageing experiment [6]. However, under the same conditions the amount of ethanol generated during the oil-only ageing experiment was much higher than that measured during the oil-paper ageing experiment [6]. The generation of methanol and ethanol from the components other than the paper could mislead the data interpretation and hence affect the paper ageing assessment. Therefore, it is important to investigate the generation of these indicators from oil itself at different conditions.

This paper investigates further into the generation of methanol and ethanol from a mineral oil. The effects of temperature and the amount of air on the generation of methanol and ethanol from the mineral oil are investigated through various laboratory ageing experiments conducted with oil-only samples.

\section{DESCRIPTION OF THE AGEING EXPERIMENTS}

Ageing experiment was conducted with inhibited IEC high-grade, naphthenic mineral oil. The oil has about $0.38 \%$ of inhibitor content in it. Prior to the ageing experiments, oil was filtered and degassed to remove particles and other contamination. First, the oil was filtered through a nylon membrane of $0.2 \mu \mathrm{m}$ to remove the particles. Then, the filtered oil was degassed inside a vacuum oven $(<500 \mathrm{~Pa})$ at $85{ }^{\circ} \mathrm{C}$ for 48 hours. Samples for the ageing experiments were prepared by adding $80 \mathrm{~g}$ of pre-processed oil into $100 \mathrm{ml}$ glass bottles. Finally, the samples were sealed with thermoplastic polyester caps that have PTFE sealing gaskets (withstand temperatures up to $180^{\circ} \mathrm{C}$ ) and left inside an air circulation oven at required temperature.

The first ageing experiment was conducted under sealed conditions at $110{ }^{\circ} \mathrm{C}, 120^{\circ} \mathrm{C}$ and $130{ }^{\circ} \mathrm{C}$ for up to 70 days, to investigate the effect of temperature on the generation of alcohols from the mineral oil.

The second ageing experiment was conducted at $130{ }^{\circ} \mathrm{C}$ with an intermittent air supply for up to 154 days to investigate the generation of the alcohols from highly aged mineral oil. Oil samples used for this experiment were taken out from the oven once every 14 days and cooled down for three hours at room temperature (about $20^{\circ} \mathrm{C}$ ). After the cooling period, one sample was used for the measurements while other samples were left open for one minute to allow air into the system. Then the samples were sealed tightly and put back into the oven to continue the ageing process. This way the fresh air was added into the samples while minimising the loss of the volatile compounds in oil including methanol and ethanol.

Methanol and ethanol in transformer oil were measured through an in-house method [4] developed based on [3]. In addition, acidity in oil was measured according to BS EN 62021 standard. 


\section{RESULTS AND DISCUSSIONS}

\section{Ageing Experiments Under Sealed Conditions}

Methanol in oil. Figure 1 shows the variation of methanol during the ageing experiment conducted at different temperatures under sealed conditions. At the investigated temperatures of $110^{\circ} \mathrm{C}, 120^{\circ} \mathrm{C}$ and $130{ }^{\circ} \mathrm{C}$, methanol in oil was less than the detection limit during the early stage of ageing, and then increased gradually till levelling-off at the late stage of ageing.

The duration that the concentration of methanol in oil is less than the detection limit reduced with the increase of temperature. The levelling-off concentration of methanol in oil increased with the increase of temperature. The levelling-off concentration values were about $0.2 \mathrm{mg} / \mathrm{kg}$, $0.25 \mathrm{mg} / \mathrm{kg}$ and $0.5 \mathrm{mg} / \mathrm{kg}$ for ageing experiments conducted at $110{ }^{\circ} \mathrm{C}, \quad 120{ }^{\circ} \mathrm{C}$ and $130{ }^{\circ} \mathrm{C}$, respectively. Alcohols are known to be one of the intermediate products of oil oxidation [7]. Therefore, the partial oil oxidation could be the main reason for the production of methanol from mineral oil. The stabilisation of methanol at the later stage of ageing might have occurred as a result of the lower rate of oil oxidation in the sealed glass bottles.

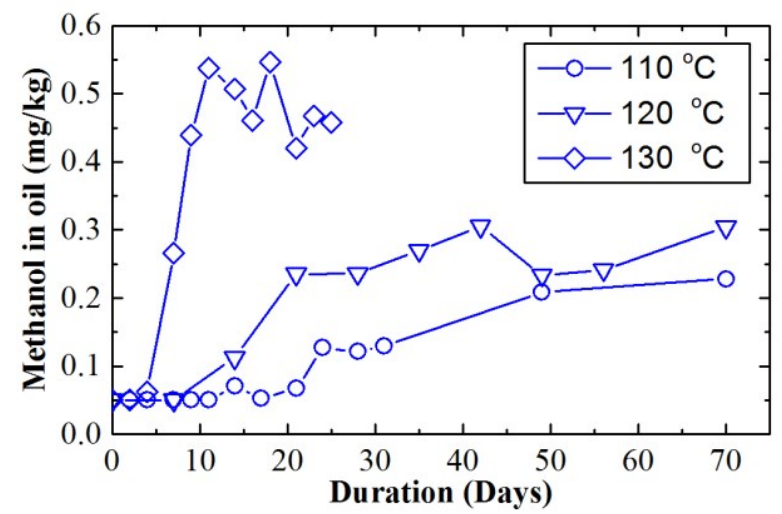

Figure 1 Variation of methanol in oil during the ageing experiment conducted under sealed conditions (without an intermittent air supply)

Acidity of oil. Figure 2 shows the variation of acidity of the mineral oil during the ageing experiments conducted under sealed conditions. The acidity of oil showed a generally increasing trend with maximum values of $0.025 \mathrm{mg} \mathrm{KOH} / \mathrm{g}$ oil, $0.045 \mathrm{mg} \mathrm{KOH} / \mathrm{g}$ oil and $0.040 \mathrm{mg} \mathrm{KOH} / \mathrm{g}$ oil for the experiments conducted at $110{ }^{\circ} \mathrm{C}, 120{ }^{\circ} \mathrm{C}$ and $130^{\circ} \mathrm{C}$, respectively. These maximum acidity values were still low and within a range that is classified as "good" condition in BS EN 60422 standard for power transformers of any voltage level. Therefore, the ageing experiment with an intermittent air supply was conducted to investigate the generation of the alcohols from oil samples at high acidity levels.

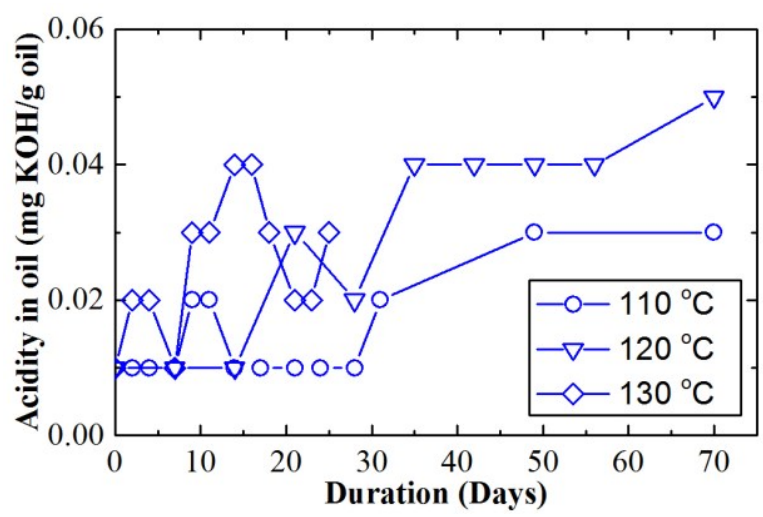

Figure 2 Variation of acidity of oil during the ageing experiment conducted under sealed conditions (without an intermittent air supply)

\section{Ageing Experiment with Intermittent Air Supply}

Acidity of oil. Figure 3 shows the variation of acidity of mineral oil during the ageing experiment conducted at $130{ }^{\circ} \mathrm{C}$ with an intermittent air supply. The acidity of oil showed a continuously increasing trend, and reached $0.44 \mathrm{mg} \mathrm{KOH} / \mathrm{g}$ oil by the end of the ageing period. The continuous increase in the acidity confirms the continuous oil oxidation in the present experiment. Furthermore, the final acidity value in oil is well above $0.30 \mathrm{mg} \mathrm{KOH} / \mathrm{g}$ oil margin, which is considered as "poor" condition in BS EN 60422 standard for power transformers of any voltage level.

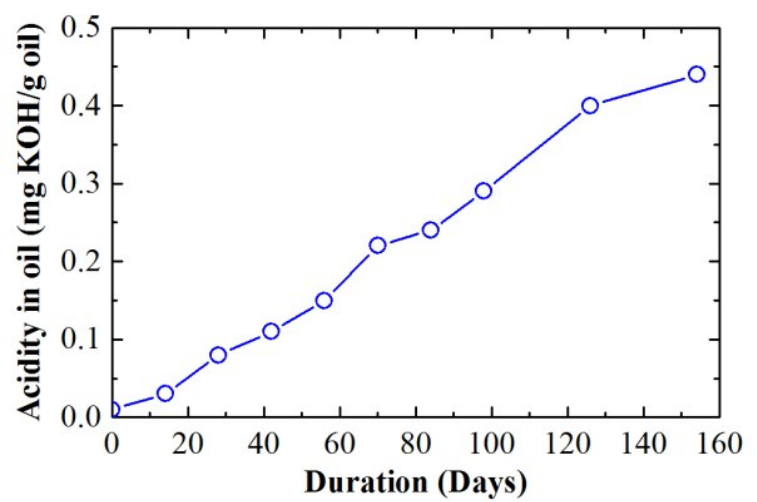

Figure 3 Variation of the acidity of oil during the ageing experiment conducted at $130{ }^{\circ} \mathrm{C}$ with an intermittent air supply

Methanol in oil. Figure 4 shows the variation of methanol in the mineral oil during the ageing at $130{ }^{\circ} \mathrm{C}$ with an intermittent air supply. Methanol in oil increased rapidly up to $0.90 \mathrm{mg} / \mathrm{kg}$ during the first 56 days with a rate of about $0.016 \mathrm{mg} / \mathrm{kg}$ per day. Methanol in oil levelled off at around 0.9 $\mathrm{mg} / \mathrm{kg}$ for the next 70 days of the ageing period. However, at the end of the ageing period methanol in oil decreased to $0.51 \mathrm{mg} / \mathrm{kg}$. The variation clearly indicates that the amount of air has an effect on the methanol production from oil. 
It is interesting to note that methanol in oil levelled off even with the continuous oil oxidation. The levelling-off concentration of methanol obtained during the ageing experiment conducted with an intermittent air supply was about twice the value obtained during the ageing experiment conducted at the same temperature without an intermittent air supply.

The levelling-off observed during the experiment conducted with an intermittent air supply might have occurred as a result of the consumption of methanol in the system. Alcohols in highly acidic mediums can undergo esterification process, which converts alcohols into esters. Equation (1) shows the reaction between methanol and formic acid, which produces methyl-formate. An equilibrium between the generation of methanol through the oxidation and the consumption of methanol through esterification likely resulted in the levelling-off of methanol in oil. At very high acidity values esterification starts to dominate resulting in an overall reduction of methanol in oil. Theoretically, a consumption of acids through esterification was expected, which unfortunately was not reflected by acidity measurement. The availability of a much larger amount of acids than the alcohols could be the reason for this observation.

$$
\mathrm{CH}_{3} \mathrm{OH}+\mathrm{HCOOH} \stackrel{\mathrm{H}^{+}}{\leftrightarrow} \mathrm{HCOOCH}_{3}+\mathrm{H}_{2} \mathrm{O}
$$

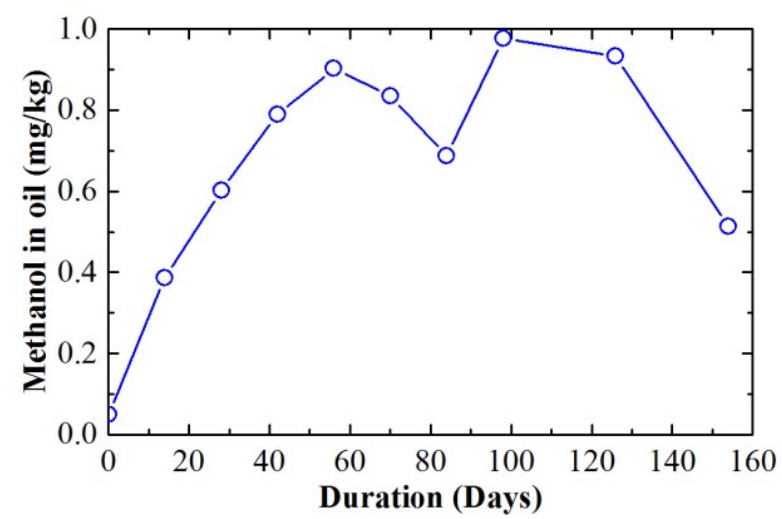

Figure 4 Variation of methanol in oil during the ageing experiment conducted at $130{ }^{\circ} \mathrm{C}$ with an intermittent air supply

Ethanol in oil. Figure 5 shows the variation of ethanol in oil during the ageing at $130{ }^{\circ} \mathrm{C}$ with an intermittent air supply. Ethanol in oil increased rapidly up to $1.77 \mathrm{mg} / \mathrm{kg}$ within 70 days with a rate of about $0.025 \mathrm{mg} / \mathrm{kg}$ per day, which is higher than that of methanol in oil. Beyond 70 days, ethanol in oil kept increasing with a lower rate till reaching $2.01 \mathrm{mg} / \mathrm{kg}$ at the end of the ageing period. Similar to methanol, the levelling-off in ethanol might be due to the esterification of ethanol in oil.

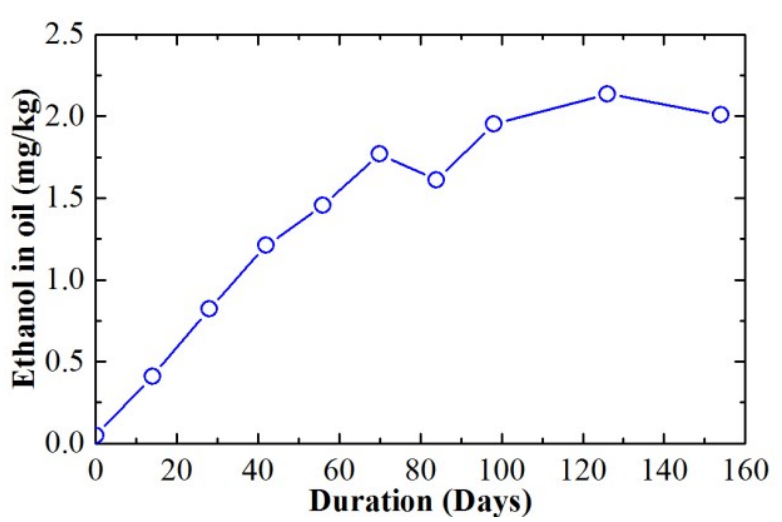

Figure 5 Variation of ethanol in oil during the ageing experiment conducted at $130{ }^{\circ} \mathrm{C}$ with an intermittent air supply

Methanol and ethanol generation against the acidity of oil. The variation of methanol and ethanol in oil was plotted against the acidity of oil as shown in Figure 6. Methanol in the oil showed a generally increasing trend at low acidity values and increased up to $0.9 \mathrm{mg} / \mathrm{kg}$ at an acidity value of $0.15 \mathrm{mg} \mathrm{KOH} / \mathrm{g}$ oil. Methanol in oil then levelled off with further increase in acidity. When the acidity of oil is higher than $0.4 \mathrm{mg} \mathrm{KOH} / \mathrm{g}$ oil, methanol in oil reduced with further increase in acidity.

Ethanol in oil increased continuously with the increase in acidity. However, the rate of increase gradually decreased and finally reached a peak value at an acidity value of $0.4 \mathrm{mg} \mathrm{KOH} / \mathrm{g}$ oil. Above this acidity value, ethanol in oil also showed a reduction trend with further increase in acidity.

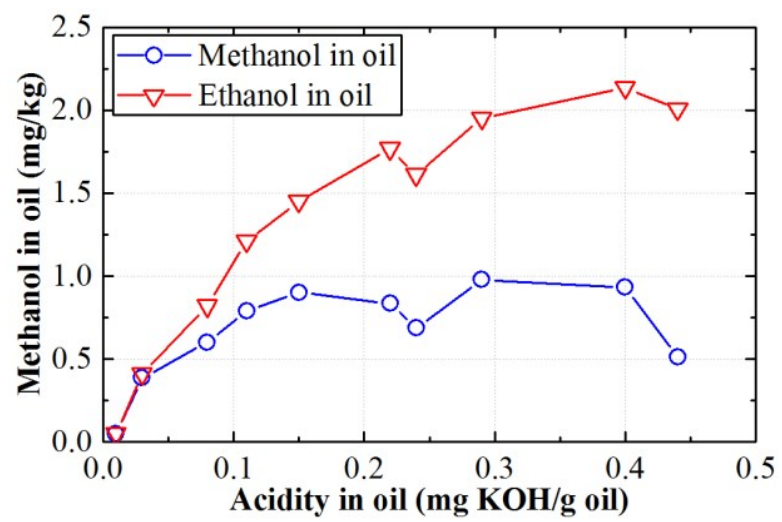

Figure 6 Variation of methanol and ethanol in oil against the acidity of oil measured during the ageing experiment conducted with an intermittent air supply

The concentration of ethanol measured in the mineral oil was higher than the concentration of methanol in oil, and the difference increased with the increase of the acidity of oil. When the acidity of oil increased beyond $0.3 \mathrm{mg} \mathrm{KOH} / \mathrm{g}$ oil ethanol in oil was about twice the amount of methanol in oil. 
The results of the ageing experiments indicate a three-stage process in the variation of methanol and ethanol in the mineral oil.

- At low acidity values, methanol and ethanol in oil increased with ageing, due to the generation from oil partial oxidation.

- When the acidity of oil increased beyond a certain level, methanol in oil levelled off while ethanol in oil continued to increase with a lower rate. This could have occurred due to the consumption of some of the alcohols generated from oil through the esterification process.

- Methanol and ethanol in oil reduced at very high acidity values. This might have occurred due to the domination of the consumption of the alcohols through esterification over the generation of alcohols through oxidation.

\section{CONCLUSIONS}

Effect of temperature on the generation of methanol from an inhibited mineral oil was investigated through a laboratory ageing experiment conducted at $110{ }^{\circ} \mathrm{C}, 120{ }^{\circ} \mathrm{C}$ and $130{ }^{\circ} \mathrm{C}$. The increase in the temperature resulted in an increase of the rate of methanol production from oil. However, methanol in oil levelled off at the later stage of the ageing experiments conducted at all the three temperatures, possibly due to the lack of oxygen in the sealed system.

Another laboratory ageing experiment was conducted at $130{ }^{\circ} \mathrm{C}$ with an intermittent air supply to investigate the effect of continuous oxidation on the generation of methanol and ethanol from the mineral oil. The experiment was conducted until the acidity of oil increased up to $0.45 \mathrm{mg} \mathrm{KOH} / \mathrm{g}$ oil. Adding new air to the system led to a substantial increase in the production of alcohols from the oil. This indicates the possible contribution from oil oxidation to the generation of these alcohols from the mineral oil. However, a reduction trend of methanol and ethanol was observed at high acidic levels of about $0.4 \mathrm{mg} \mathrm{KOH} / \mathrm{g}$ oil, which might have occurred due to the consumption of the alcohols in oil through the esterification.

\section{ACKNOWLEDGEMENT}

The authors would like to express their gratitude to M\&I Materials, National Grid, Scottish Power, Shell Global Solutions, TJ|H2b Analytical Services, UK Power Networks and WEIDMANN Electrical Technology for their financial and technical contributions to the transformer research consortium at The University of Manchester. The authors would also like to thank Desmond Doocey, Elizabeth Davenport and the staff in the Mill-B9 laboratory,
School of Chemical Engineering \& Analytical Science for their support during GC-MS measurement.

\section{References}

1 L. E. Lundgaard, W. Hansen, D. Linhjell, and T. J. Painter, "Aging of oilimpregnated paper in power transformers," IEEE Transactions on, Power Delivery, vol. 19, pp. 230-239, 2004.

2 J. Jalbert, R. Gilbert, P. Tétreault, B. Morin, and D. Lessard-Déziel, "Identification of a chemical indicator of the rupture of 1,4- $\beta$-glycosidic bonds of cellulose in an oil-impregnated insulating paper system," Cellulose, vol. 14, pp. 295-309, 2007.

3 J. Jalbert, S. Duchesne, E. RodriguezCelis, P. Tétreault, and P. Collin, "Robust and sensitive analysis of methanol and ethanol from cellulose degradation in mineral oils, "Journal of Chromatography A, vol. 1256, pp. 240245, 2012.

4 S. Y. Matharage, Q. Liu, E. Davenport, G. Wilson, D. Walker, and Z. D. Wang, "Methanol detection in transformer oils using gas chromatography and ion trap mass spectrometer," in IEEE 18th International Conference on Dielectric Liquids (ICDL), pp. 1-4, 2014.

5 E. M. Rodriguez-Celis, S. Duchesne, J. Jalbert, and M. Ryadi, "Understanding ethanol versus methanol formation from insulating paper in power transformers," Cellulose, vol. 22, pp. 3225-3236, 2015.

6 S. Y. Matharage, Q. Liu, and Z. D. Wang, "Ageing Assessment of Kraft Paper Insulation through Methanol in Oil Measurement," IEEE Transactions on Dielectrics and Electrical Insulation, vol. 23, pp. 1589-1596, June 2016.

7 "Oxidation stability of insulating fluids," CIGRE Brochure 526, 2013. 